\title{
Notes on the contributors
}

\section{Dr Jayne H. Glass}

Jayne Glass is a Research Associate at the Centre for Mountain Studies, Perth College, University of the Highlands and Islands, Scotland, and holds degrees in geography and in environmental sustainability from the universities of Oxford and Edinburgh. She recently completed a $\mathrm{PhD}$ in Sustainability Studies at the University of the Highlands of Islands on knowledge co-production for sustainable upland estate management in Scotland (awarded by the University of Aberdeen).

\section{Professor Martin F. Price}

Martin Price is Director of the Centre for Mountain Studies, Perth College, University of the Highlands and Islands, Scotland, and holds the UNESCO Chair for Sustainable Mountain Development. He previously worked at the universities of Oxford, Bern, and Colorado, and at the National Center for Atmospheric Research. Books he has edited include Mountain Geography: Physical and Human Dimensions (2013), Mountain Area Research and Management (2007), The Mountains of Northern Europe (2005), and Key Issues for Mountain Areas (2004).

\section{Dr Charles R. Warren}

Charles Warren is Senior Lecturer in the Department of Geography and Sustainable Development at the University of St Andrews, and holds degrees in geography, glaciology, and resource management from Oxford and Edinburgh universities. He has written widely on Scottish land-use issues, including his book Managing Scotland's Environment (Edinburgh University Press, 2009). He also co-edited Learning from Wind Power: Governance, Societal and Policy Perspectives on Sustainable Energy (2012).

\section{Professor Alister J. Scott}

Alister Scott is Professor of Environment and Spatial Planning at Birmingham City University. He is a chartered planner with roots firmly in geography. His research and teaching are located within an interdisciplinary framework with a focus on complex and messy policy and land-use problems. He has become an expert at the interface of spatial planning and the ecosystem approach with projects exploring the rural urban fringe as part of the RELU programme (2009-11) and the embedding of the ecosystem approach in tools for improved policy- and decision-making as part of the National 
Xviii

NOTES ON THE CONTRIBUTORS

Ecosystem Assessment (NEA) Follow-on project 2012-14. He also sits on the NEA expert panel and is a communication adviser for the NERC BESS programme.

\begin{abstract}
Annie J. McKee
Annie McKee is an early career researcher and Research Assistant in the Social, Economic and Geographical Science Group at the James Hutton Institute in Aberdeen, Scotland. She holds degrees in geography and sustainable rural development from St Andrews and Aberdeen universities, and is currently completing her PhD with the Centre for Mountain Studies at Perth College, University of the Highlands and Islands. Annie is a Trustee of the Andrew Raven Trust, and board member of the Rural Housing Service.
\end{abstract}

\title{
Pippa K. Wagstaff
}

Pippa Wagstaff is a $\mathrm{PhD}$ researcher at the Centre for Mountain Studies, Perth College, University of the Highlands and Islands, Scotland and holds a first degree from the Open University and a Masters in Land Economy from the University of Aberdeen. Pippa had a previous career as a chartered accountant. She is currently completing her $\mathrm{PhD}$ on landowner motivation as part of the Sustainable Estates project.

\section{Dr Robert Mc Morran}

Rob Mc Morran is a Research Associate at the Centre for Mountain Studies, Perth College, University of the Highlands and Islands. Rob is an interdisciplinary researcher with experience in qualitative and GIS methodologies and specific interests in conceptions of wildness; sustainable rural governance and multifunctional land use; and policy processes relating to rural and mountainous regions. Rob has acted as a consultant to Scottish Natural Heritage, Forestry Commission Scotland, Scotland's National Park Authorities, the Scottish Countryside Alliance, and the John Muir Trust. Rob's research is predominantly applied, with recent research on mountain food-supply chains in Europe resulting directly in changes to EU Policy. Rob is an Honorary Research Associate of the Wildland Research Institute (University of Leeds) and a member of the BBC Scotland Rural Affairs Committee. 